\title{
PrognoScan: a new database for meta-analysis of the prognostic value of genes
} Hideaki Mizuno*1,2, Kunio Kitada1 $^{1}$, Kenta Nakai ${ }^{3}$ and Akinori Sarai ${ }^{2}$

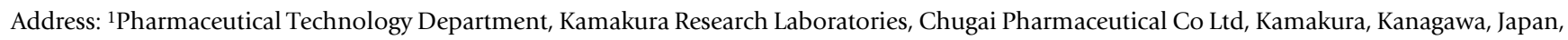
${ }^{2}$ Department of Biosciences and Bioinformatics, Kyushu Institute of Technology, Iizuka, Fukuoka, Japan and ${ }^{3}$ Human Genome Center, Institute of Medical Science, University of Tokyo, Minato-ku, Tokyo, Japan

Email: Hideaki Mizuno* - mizunohda@chugai-pharm.co.jp; Kunio Kitada - kitadakno@chugai-pharm.co.jp; Kenta Nakai - knakai@ims.utokyo.ac.jp; Akinori Sarai - sarai@bse.kyutech.ac.jp

* Corresponding author

Published: 24 April 2009

BMC Medical Genomics 2009, 2:18 doi:10.1186/1755-8794-2-18
Received: 17 December 2008

Accepted: 24 April 2009

This article is available from: http://www.biomedcentral.com/1755-8794/2/18

(C) 2009 Mizuno et al; licensee BioMed Central Ltd.

This is an Open Access article distributed under the terms of the Creative Commons Attribution License (http://creativecommons.org/licenses/by/2.0), which permits unrestricted use, distribution, and reproduction in any medium, provided the original work is properly cited.

\begin{abstract}
Background: In cancer research, the association between a gene and clinical outcome suggests the underlying etiology of the disease and consequently can motivate further studies. The recent availability of published cancer microarray datasets with clinical annotation provides the opportunity for linking gene expression to prognosis. However, the data are not easy to access and analyze without an effective analysis platform.

Description: To take advantage of public resources in full, a database named "PrognoScan" has been developed. This is I) a large collection of publicly available cancer microarray datasets with clinical annotation, as well as 2) a tool for assessing the biological relationship between gene expression and prognosis. PrognoScan employs the minimum $P$-value approach for grouping patients for survival analysis that finds the optimal cutpoint in continuous gene expression measurement without prior biological knowledge or assumption and, as a result, enables systematic meta-analysis of multiple datasets.

Conclusion: PrognoScan provides a powerful platform for evaluating potential tumor markers and therapeutic targets and would accelerate cancer research. The database is publicly accessible at http://gibk2l.bse.kyutech.ac.jp/PrognoScan/index.html.
\end{abstract}

\section{Background}

A number of genes are recognized as being potentially relevant to cancers. One way to evaluate such genes is to assess their relationship to prognosis. At present, many cancer microarray datasets with clinical annotation have become available in the public domain and provide vast opportunities to link gene expression to prognosis. However, the data are not easy to access and analyze without an effective analysis platform.
Standard survival analysis consists of two steps: 1) grouping patients and 2) comparing the risk difference of the groups. When conducting survival analysis based on continuous measurement such as gene expression, determination of the appropriate cutpoints for groupings remains a critical and difficult task. Thus, although two pioneer databases, ITTACA [1] and REMBRANDT http://rem brandt.nci.nih.gov, have provided survival analysis functionality with user defined cutpoints for several focused 
cancer microarray datasets, researchers without prior biological knowledge or assumptions for the gene may end up using an arbitrary threshold (e.g. median, tertile, quartile) that does not necessarily reflect the biology of the gene or may laboriously test a number of possible cutpoints.

The minimum $P$-value approach is a comprehensive method to find the optimal risk separation cutpoint in continuous measurements and have shown the utility in the analyses of tumor size [2], cell cycle phase estimation measurement [3], and gene copy number [4]. In addition, it is intuitive for oncologists, and thus, a systematic application of this approach to gene expression from microarray seems logical. Recent studies have reported expression thresholds at which the gene becomes a contributor to the development of the cancer such as Bub1 for tumorigenesis [5], HOXB4 for cellular transformation [6], and MYC for tumor maintenance [7], and provided a rationale for the application to gene expression. Thus, we developed "PrognoScan", a database featuring a large collection of publicly available cancer microarray datasets with clinical annotation and a tool for assessing the relationship between gene expression and prognosis using the minimum $P$-value approach. This database enables systematic meta-analysis of the prognostic value of a gene in multiple datasets and consequently will accelerate cancer research.

\section{Construction and content Data collection}

Cancer microarray datasets with clinical annotation were intensively collected from the public domain including Gene Expression Omnibus (GEO) [8], ArrayExpress [9] and individual laboratory web sites, under the following criteria: 1) includes patient information on survival event and time, 2) contains large enough sample sizes to enable survival analysis, 3) is derived from a 'whole genome' platform and has no values missing so quantile normalization will function properly and 4 ) is derived from a platform for which probe annotation for a public identifier (e.g. gene symbol, GenBank accession number, UniGene ID) is available. As of February 2009, the collection included more than 40 datasets of various cancer types spanning a wide range of cancers including bladder, blood, breast, brain, esophagus, head and neck, kidney, lung, and ovarian (Table 1) [10-35], far more comprehensive than both ITTACA, which focuses on bladder cancer, breast cancer and uveal melanoma, and REMBRANDT, which specializes in brain cancers. Because some samples were used more than once by more than one study, the origin of the samples was checked. Sample duplications within a dataset were dealt with by leaving one representative arbitrary. Sample overlaps among datasets were accepted, because the study design designated by each contributor may be of value. The collected microarray datasets were standardized by using quantile normalization. Probe annotations were retrieved from GEO and ArrayExpress. Each probe was mapped to an Entrez Gene ID by querying the accompanied public identifier in UniGene database. The information in the dataset was manually curated and includes 1) study design-cohort, cancer type, subtype, endpoint, therapy history and pathological parameters-and 2) experimental procedure-sample preparation, storage, array type and signal processing method. To assess prognostic value of genes in various contexts, available endpoints such as overall survival (OS), recurrence free survival (RFS), event free survival (EFS), and distant-metastasis free survival (DMFS) were adopted as much as possible. All tables were relationally linked and stored in the MySQL server.

\section{Data analysis}

Survival analysis in PrognoScan employs the minimum $P$ value approach [2] to find the cutpoint in continuous gene expression measurement for grouping patients. First, patients are ordered by expression value of a given gene. Next, patients are divided into two (high and low) expression groups at all potential cutpoint, and the risk differences of the two groups are estimated by log-rank test. Then, optimal cutpoint that gives the most pronounced $P$ value $\left(P_{\min }\right)$ is selected.

This exploratory approach, however, is known to cause inflation of a type I error because it conducts multiple correlated testing [36-38]. Thus, $P$-value correction is conducted to control the error rate using the following formula [39].

$$
P_{\text {cor }}=4 \varphi(z) / z+\varphi(z)\{z-(1 / z)\} \log \left\{(1-\varepsilon)^{2} / \varepsilon^{2}\right\}
$$

where $z$ is the $\left(1-P_{\min } / 2\right)$-quantile of the standard normal distribution, $\phi$ denotes the standard normal density function, and $[\varepsilon, 1-\varepsilon]$ denote the range of the quantile considered to be cutpoints. PrognoScan uses $\varepsilon=0.1$ to avoid small groupings from cutpoints of $<0.1$ or $>0.9$ quantile. For any given gene, this cutpoint determination and prognostic value assessment can be applied to all possible combinations of dataset, endpoint and probe. For convenience, we term each combination as "test". Note that, because probe design for each gene differs, the number of possible tests varies according to the gene. For statistical analysis and visualization, $\mathrm{R}$ packages http://www.rproject.org are used.

\section{Utility}

The top page of PrognoScan is quite simple and the user need only input gene identifier(s) (Fig. 1A). To show the features of the database and its utility, we give three metaanalysis examples. The first example is MKI67, a well known tumor proliferation marker. The prognostic value 
Table I: Dataset content from PrognoScan

\begin{tabular}{|c|c|c|c|c|c|c|c|}
\hline Dataset & Cancer type & Subtype & Cohort & $\begin{array}{l}\text { Authorl } \\
\text { Contributor }\end{array}$ & Array type & $n$ & Data source \\
\hline GSEI 3507 & Bladder cancer & $\begin{array}{l}\text { Transitional cell } \\
\text { carcinoma }\end{array}$ & Cheongju & Kim & Human-6 v2 & $n=165$ & GEO \\
\hline GSE5287 & Bladder cancer & & Aarhus (1995-2004) & Als et al. [10] & HG-UI33A & $n=30$ & GEO \\
\hline GSEI 24I I-GPL570 & Blood cancer & AML & AMLCG (2004) & Metzeler et al. [I I] & HG-UI33_Plus_2 & $n=79$ & GEO \\
\hline GSEI24|7-GPL96 & Blood cancer & AML & AMLCG (1999-2003) & Metzeler et al. [I I] & HG-UI33A & $n=163$ & GEO \\
\hline GSEI24|7-GPL97 & Blood cancer & AML & AMLCG (1999-2003) & Metzeler et al. [I I] & HG-UI33B & $n=163$ & GEO \\
\hline GSE8970 & Blood cancer & AML & San Diego & Raponi et al. [12] & HG-UI33A & $n=34$ & GEO \\
\hline GSE4475 & Blood cancer & B-cell lymphoma & Berlin (2003-2005) & Hummel et al. [13] & HG-UI33A & $n=158$ & GEO \\
\hline E-TABM-346 & Blood cancer & DLBCL & GELA (I998-2000) & Jais et al. [14] & HG-UI33A & $n=53$ & ArrayExpress \\
\hline GSE2658 & Blood cancer & Multiple myeloma & Arkansas & Zhan et al. [15] & HG-UI33_Plus_2 & $n=559$ & GEO \\
\hline E-TABM- 158 & Breast cancer & & UCSF, CPMC (1989-1997) & Chin et al. [16] & HG-UI33A & $n=129$ & ArrayExpress \\
\hline GSEIII2I & Breast cancer & & Mainz (1988-1998) & Schmidt et al. [17] & HG-UI33A & $n=200$ & GEO \\
\hline GSEI 378 & Breast cancer & & MGH (1987-2000) & Ma et al. [18] & Arcturus $22 \mathrm{k}$ & $\mathrm{n}=60$ & GEO \\
\hline GSEI 379 & Breast cancer & & MGH (1987-2000) & Ma et al. [18] & Arcturus $22 \mathrm{k}$ & $\mathrm{n}=60$ & GEO \\
\hline GSEI456-GPL96 & Breast cancer & & Stockholm (1994-1996) & Pawitan et al. [19] & HG-UI33A & $n=159$ & GEO \\
\hline GSEI456-GPL97 & Breast cancer & & Stockholm (1994-1996) & Pawitan et al. [19] & HG-UI33B & $n=159$ & GEO \\
\hline GSE2034 & Breast cancer & & Rotterdam (1980-1995) & Wang et al. [20] & HG-UI33A & $n=286$ & GEO \\
\hline GSE2990 & Breast cancer & & Uppsala, Oxford & Sotiriou et al. [2I] & HG-UI33A & $\mathrm{n}=187$ & GEO \\
\hline GSE3 I 43 & Breast cancer & & Duke & Bild et al. [22] & HG-U95A & $n=158$ & GEO \\
\hline GSE3494-GPL96 & Breast cancer & & Uppsala (1987-1989) & Miller et al. [23] & HG-UI33A & $n=236$ & GEO \\
\hline GSE3494-GPL97 & Breast cancer & & Uppsala (1987-1989) & Miller et al. [23] & HG-UI33B & $n=236$ & GEO \\
\hline GSE4922-GPL96 & Breast cancer & & Uppsala (1987-1989) & Ivshina et al. [24] & HG-UI33A & $n=249$ & GEO \\
\hline GSE4922-GPL97 & Breast cancer & & Uppsala (1987-1989) & Ivshina et al. [24] & HG-UI33B & $n=249$ & GEO \\
\hline GSE6532-GPL570 & Breast cancer & & GUYT & Loi et al. [25] & HG-UI33_Plus_2 & $\mathrm{n}=87$ & GEO \\
\hline GSE7378 & Breast cancer & & UCSF & Zhou et al. [26] & UI33AAofAv2 & $n=54$ & GEO \\
\hline GSE7390 & Breast cancer & & $\begin{array}{l}\text { Uppsala, Oxford, Stockholm, IGR, } \\
\text { GUYT, CRH (1980-1998) }\end{array}$ & Desmedt et al. [27] & HG-UI33A & $n=198$ & GEO \\
\hline GSE7849 & Breast cancer & & Duke (I990-200I) & Anders et al. [28] & HG-U95A & $n=76$ & GEO \\
\hline GSE9195 & Breast cancer & & GUYT2 & Loi et al. [25] & HG-UI33_Plus_2 & $n=77$ & GEO \\
\hline GSE9893 & Breast cancer & & $\begin{array}{l}\text { Montpellier, Bordeaux, Turin (1989- } \\
2001 \text { ) }\end{array}$ & Chanrion et al. [29] & $\begin{array}{l}\text { MLRG Human } 21 \mathrm{~K} \\
\text { VI } 2.0\end{array}$ & $\mathrm{n}=155$ & GEO \\
\hline GSEII595 & Esophagus cancer & Adenocarcinoma & Sutton & Giddings & $\begin{array}{l}\text { CRUKDMF_22 } \\
\text { K_v1.0.0 }\end{array}$ & $\mathrm{n}=34$ & GEO \\
\hline GSE7696 & Glioma & Glioblastoma & Lausanne & Murat et al. [30] & HG-UI33_Plus_2 & $\mathrm{n}=70$ & GEO \\
\hline GSE427I-GPL96 & Glioma & & MDA & Phillips et al. [3I] & HG-UI33A & $n=77$ & GEO \\
\hline GSE427I-GPL97 & Glioma & & MDA & Phillips et al. [3I] & HG-UI33B & $\mathrm{n}=77$ & GEO \\
\hline GSE2837 & $\begin{array}{l}\text { Head and neck } \\
\text { cancer }\end{array}$ & $\begin{array}{l}\text { Squamous cell } \\
\text { carcinoma }\end{array}$ & $\begin{array}{l}\text { VUMC, VAMC, UTMDACC (1992- } \\
2005)\end{array}$ & Chung et al. [32] & U133_X3P & $n=28$ & GEO \\
\hline HARVARD-LC & Lung cancer & Adenocarcinoma & Harvard & Beer et al. [33] & HG-U95A & $\mathrm{n}=84$ & Author's web site \\
\hline MICHIGAN-LC & Lung cancer & Adenocarcinoma & Michigan (1994-2000) & Beer et al. [33] & HuGeneFL & $\mathrm{n}=86$ & Author's web site \\
\hline GSEIIII7 & Lung cancer & NSCLC & Basel & Baty & Novachip human $34.5 \mathrm{k}$ & $n=4 l$ & GEO \\
\hline GSE3|4I & Lung cancer & NSCLC & Duke & Bild et al. [22] & HG-UI33_Plus_2 & $n=111$ & GEO \\
\hline GSE47I6-GPL3694 & Lung cancer & NSCLC & Nagoya (1995-1996) & Tomida et al. [34] & GF200 & $n=50$ & GEO \\
\hline
\end{tabular}


Table I: Dataset content from PrognoScan (Continued)

\begin{tabular}{|c|c|c|c|c|c|c|c|}
\hline GSE47I6-GPL3696 & Lung cancer & NSCLC & Nagoya (1995-1996) & Tomida et al. [34] & GF20I & $\mathrm{n}=50$ & GEO \\
\hline GSE8894 & Lung cancer & $\mathrm{NSCLC}$ & Seoul & Son & HG-UI33_Plus_2 & $n=138$ & GEO \\
\hline GSE4573 & Lung cancer & $\begin{array}{l}\text { Squamous cell } \\
\text { carcinoma }\end{array}$ & Michigan (199I-2002) & Raponi et al. [35] & HG-UI33A & $n=129$ & GEO \\
\hline DUKE-OC & Ovarian cancer & & Duke & Bild et al. [22] & HG-UI33A & $n=134$ & Author's web site \\
\hline GSE884I & Ovarian cancer & & Milan & Mariani & G4I00A & $\mathrm{n}=83$ & GEO \\
\hline E-DKFZ-I & Renal cell carcinoma & & RZPD & Sueltmann & A-RZPD-20 & $\mathrm{n}=74$ & ArrayExpress \\
\hline
\end{tabular}

Abbreviations: AML, Acute myelocytic leukemia; DLBCL, Diffuse large B-cell lymphoma; NSCLC, Non-small cell lung cancer 
A

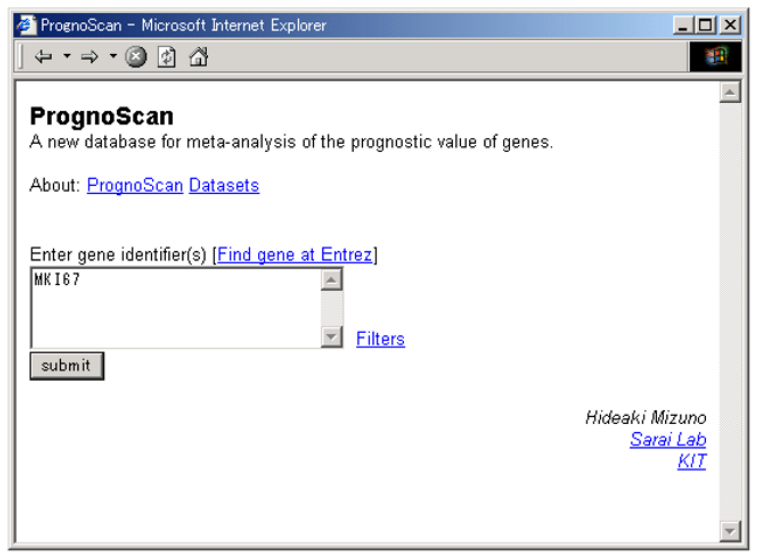

B

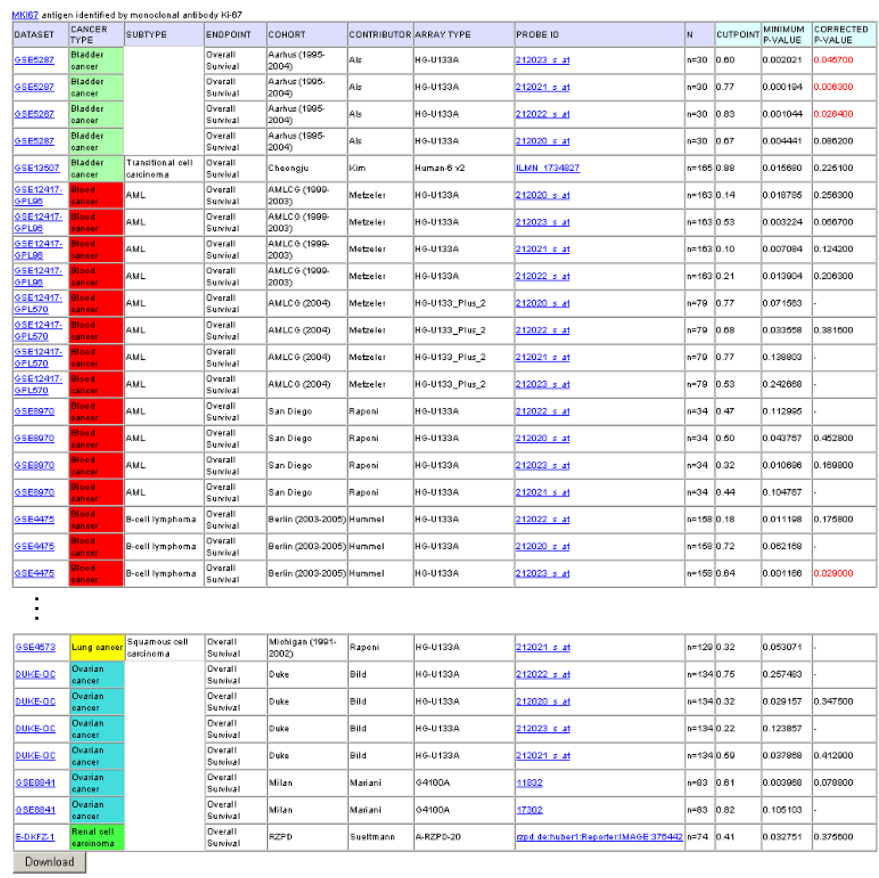

Figure I

PrognoScan screenshot and sample search results (part I). (A) The top page is quite simple and only requires entering the gene identifier(s). (B) Summary table for MKI67, shown here in part (See Additional file I for the full table.). Column headings include dataset, cancer type, subtype, endpoint, cohort, contributor, array type, probe ID, number of patients, optimal cutpoint, $P_{\min }$ and $P_{\text {cor. }}$. A statistically significant value of $P_{\text {cor }}$ is given in red font. Each dataset has a link to the public domain where the raw data is archived. By clicking a probe ID in the summary table, a detailed report for the test is displayed. The table can be downloaded in a tab delimited file from the button at bottom.

of MKI67 protein expression has been reported for many types of malignant tumor including brain, breast, and lung cancer and a few exceptions for certain tumors such as non-Hodgkin's lymphoma [40]. When given the gene, PrognoScan displays a summary in table format of tests for the gene with columns for dataset, cancer type, subtype, endpoint, cohort, contributor, array type, probe ID, number of patient, optimal cutpoint, $P_{\min }$ and $P_{\text {cor }}$ as Fig. $1 \mathrm{~B}$ for MKI67 (shown in full in Additional file 1). In the table, 52 out of 152 tests showed an association between microarray expression and cancer prognosis (bladder 3/5, blood $6 / 28$, breast $39 / 83$, brain $3 / 8$, esophagus $0 / 1$, head and neck $0 / 4$, kidney $0 / 1$, lung $1 / 16$, ovarian $0 / 6$ ) with $5 \%$ significance level. Clicking the probe ID in the list reveals a detailed report, which includes further annotations for the dataset (Fig. 2A) and four intuitive visualization panels (Fig. 2B-E). The example of the Rotterdam cohort for DMFS depicts that patients can be dichotomized at the 34 percentile to give the minimum $P$-value and the group with high MKI67 expression has poorer survival $\left(P_{\text {cor }}=0.0078\right)$. We found all tests but one for B-cell lymphoma OS showed a positive correlation to poorer survival, consistent with previous study results [40]. We further confirmed that the expressions of other well known proliferation markers TOP2A, PCNA and Aurora A also showed association with poorer survival in various tests (Additional file 2).

The second example is SIX1, emerging as a tumor-susceptible gene. This homeobox gene has been shown to promote tumor progression through direct activation of Cyclin A1 $[41,42]$ and to associate with prognosis of latestage ovarian cancer [43] and hepatocellular carcinoma [44]. It has also been reported that SIX1 can be amplified and/or overexpressed in breast cancers $[45,46]$. Nonetheless, to our knowledge, association with breast cancer prognosis has not yet been demonstrated. And so we tested SIX1. For ovarian cancer, a clear association was not observed in three tests available in PrognoScan. For this cancer type, further subgrouping based on stage may be needed, as reported [43]. On the other hand, SIX1 expression was positively associated with 5 out of 28 breast cancer tests (Fig. 3; Uppsala cohort; Pcor $=0.0002,0.0006$ and 0.0449, Uppsala+Oxford cohort; Pcor $=0.0346$, Stockholm cohort; Pcor $=0.0354$ ) with statistical significance, indicative of its contribution to breast cancer 
A

\begin{tabular}{|c|c|}
\hline DATASET & GSE2034 \\
\hline CANCER_TYPE & Breast cancer \\
\hline \multicolumn{2}{|l|}{ SUBTYPE } \\
\hline N & $n=286$ \\
\hline ENDPOINT & Distant Metastasis Free Survival \\
\hline PERIOD & Months \\
\hline COHORT & Rotterdam (1980-1995) \\
\hline ARRAY TYPE & HG-U133A \\
\hline CONTRIBUTOR & Wang \\
\hline ADJUVANT THERAPY & NONE \\
\hline AGE & $26-83$ \\
\hline DATA_PROCESSING & MAS5 \\
\hline ER STATUS & Positive: $73 \%$ \\
\hline LYMPH NODE STATUS & Positive: $0 \%$ \\
\hline NEOADJUVANT THERAPY & NONE \\
\hline PR STATUS & Positive: $58 \%$ \\
\hline SAMPLE TYPE & Frozen \\
\hline THERAPY & Radio: $87 \%$ \\
\hline CUTPOINT & 0.34 \\
\hline MINIMUM P-VALUE & 0.000248 \\
\hline CORRECTED P.VALUE & 0.007800 \\
\hline
\end{tabular}

\section{Figure 2}

PrognoScan screenshot and sample search results (part 2). (A) Annotation table. Row headings are color-coded. For example, headings of details such as therapy history, sample type and pathological parameters are highlighted in yellow and basic attributes in blue. (B) Expression plot. Patients are ordered by the expression values of the given gene. The $X$-axis represents the accumulative number of patients and the $Y$-axis represents the expression value. Straight lines (cyan) show the optimal cutpoints that dichotomize patients into high (red) and low (blue) expression groups. (C) Expression histogram. The distribution of the expression value is presented where the $X$-axis represents the number of patients and the $Y$-axis represents the expression value on the same scale as the expression plot. The line of the optimal cutpoint is also shown (cyan). (D) $P$-value plot. For each potential cutpoint of expression measurement, patients are dichotomized and survival difference between high and low expression groups is calculated by log-rank test. The $X$-axis represents the accumulative number of patients on the same scale as the expression plot and the $Y$-axis represents raw $P$-values on a log scale. The cutpoint to minimize the $P$-value is determined and indicated by the cyan line. The gray line indicates the $5 \%$ significance level. (E) Kaplan-Meier plot. Survival curves for high (red) and low (blue) expression groups dichotomized at the optimal cutpoint are plotted. The $X$-axis represents time and the $\mathrm{Y}$-axis represents survival rate. $95 \%$ confidence intervals for each group are also indicated by dotted lines.

malignancy. In addition, SIX1 expression showed nonsignificant trend toward worse prognosis in the GUYT2 and MGH cohorts (Pcor $=0.0601,0.0729$, respectively). Using PrognoScan, SIX1 expression was correlated to breast cancer prognosis in multiple tests for the first time.

The third example is MCTS1, a candidate oncogene amplified in T cell lymphoma. MCTS 1 in a xenograft model causes transformation of NIH 3T3 mouse fibroblasts [47] and increases tumorgenicity by promoting angiogenesis and inhibiting apoptosis [48]. Similar to SIX1, prognostic analysis of this gene has not been reported for any cancers. PrognoScan depicted statistical significance in several tests: blood $2 / 7$, breast $4 / 21$, brain $1 / 2$, lung $2 / 5$ (Fig. 4 ). In all these 9 tests, a higher expression of MCTS1 associated with poorer survival, suggesting proactive involvement of this gene in the malignancy in the cancers. Again, this prognostic analysis was the first to show these relationships.

\section{Discussion and conclusion}

PrognoScan is a database that focuses on the prognostic value of individual genes and differs conceptually from gene signatures. van't Veer et al. showed that the '70 gene signature' can predict risk of breast cancer recurrence, and that pattern analysis of multifactorial gene signature has greater potential for improving cancer subtype classification and risk prediction [49]. On the other hand, the prognostic value of an individual gene, for which pattern analysis is not applicable, suggests underlying relevance of the gene to cancer etiology and in turn stimulates research. With the number of public cancer microarray datasets with clinical annotation currently available, it is reasonable to utilize those assets to link gene expression to prognosis. Actually, Mehra et al., Paulson et al., and Kim et al. interrogated published cancer microarray datasets to evaluate targeted genes, GATA3, HBP1 and CUL7, respectively [50-52]. In this study, candidate oncogene SIX1 was correlated to breast cancer prognosis and MCTS1 to brain, 

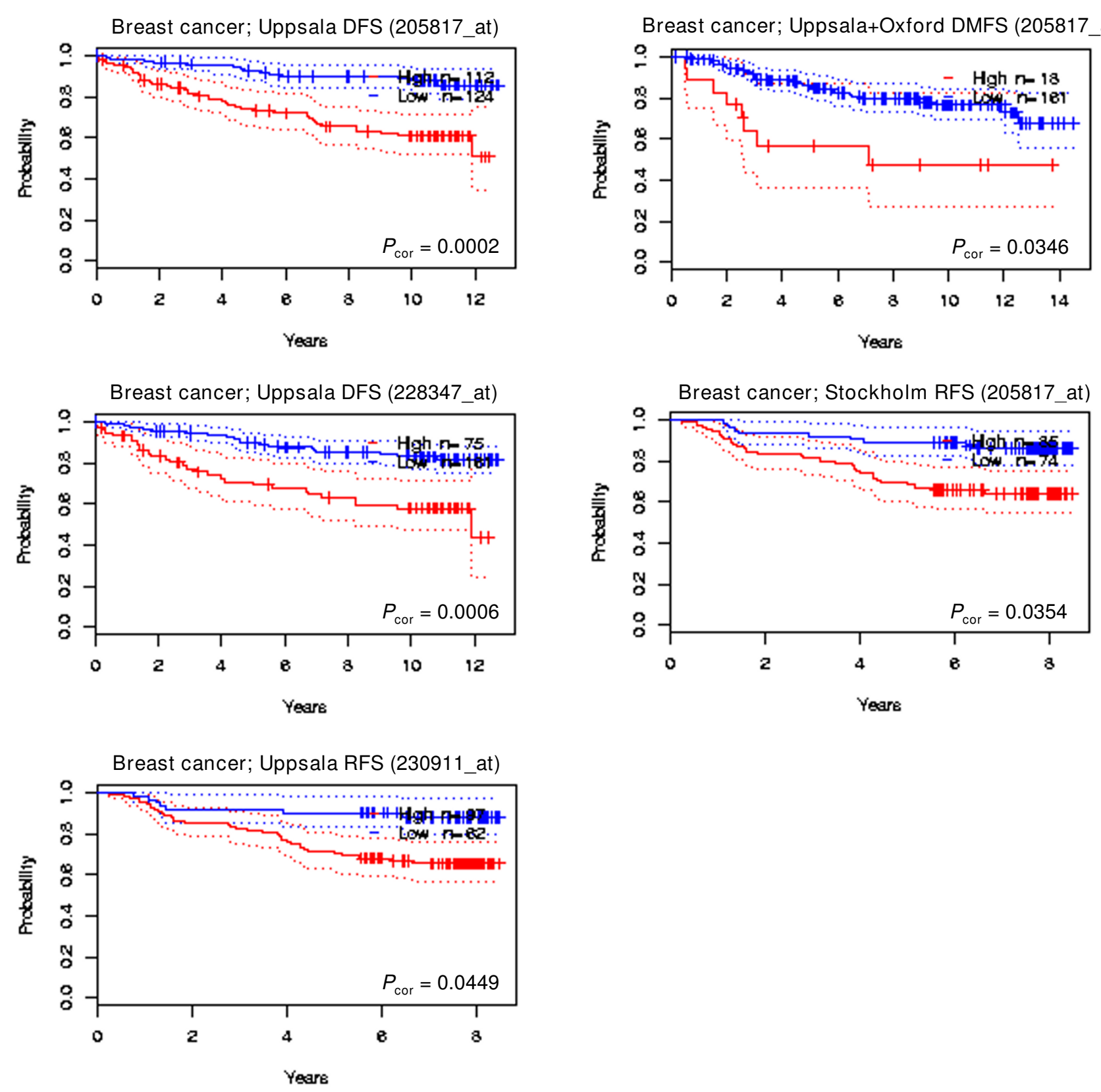

Figure 3

Kaplan-Meier plots for high and low SIX I-expressing groups in breast cancers.

blood, breast and lung cancer prognosis for the first time. PrognoScan aims to fulfill such substantial practical requirements.

Regarding survival analysis using publicly available microarray datasets, several considerations exist:

1) Cohorts. Datasets come from a number of different institutions around the world, and patient backgrounds differ. In addition, several datasets are based on specific subpopulations, for example, dataset GSE2034 is from lymph node-negative breast cancers, and GSE5287 is from cisplatin-containing chemotherapy-treated bladder cancers. Hence, it is possible that the specific association between gene expression and prognosis is found in a certain cohort. To give an example, Dai et al. reported that cell cycle genes are highly prognostic in groups with high 

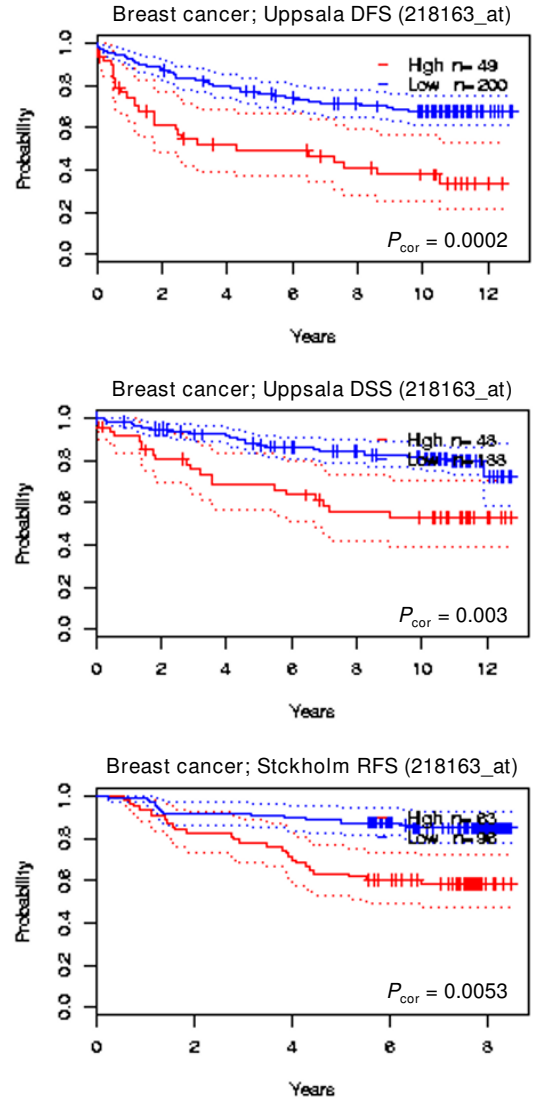

Breast cancer; Mainz DMFS (218163 at)
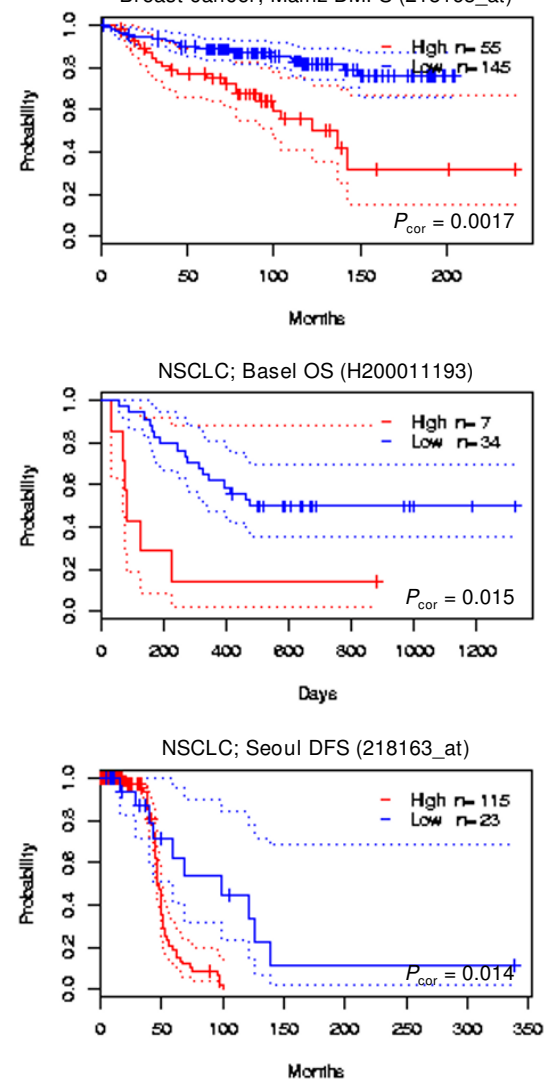

Multiple Myeloma; Arkansas CSS (218163 at)
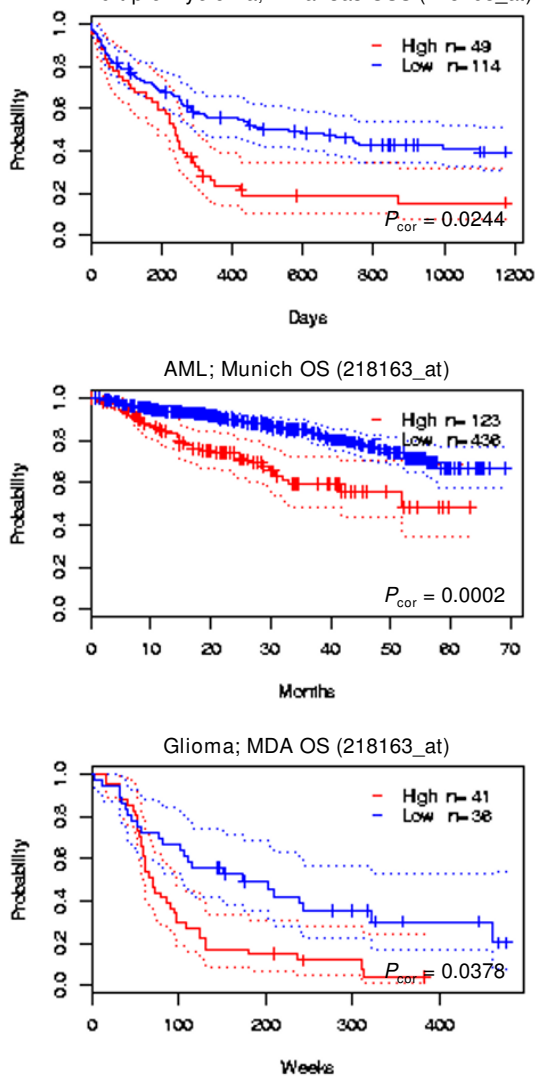

\section{Figure 4}

Kaplan-Meier plots for high and low MCTSI-expressing groups in breast, lung, blood and brain cancers.

ER expression for their age but less or nonprognostic in other groups [53].

2) Quality of care. It has been reported that the hospital itself could be a factor in clinical outcome [54-56]. This means, even if cohorts were equivalent at the time of profiling, subsequent care may affect the clinical course of a patient.

3) Experimental factors. Expression measurement of microarray is subject to various factors at the experiment level. Microdissection (e.g. GSE1378) would reduce contamination of mRNAs from non-cancer cells [57]. Formalin fixation of a sample (e.g. GSE2873) influences the quality of mRNAs [58]. Array type (e.g. Affymetrix, cDNA microarrays) and data processing method (e.g. MAS, RMA) can also influence gene expression measurements [59]. In addition, it is known that a substantial number of incorrect probes are used in microarrays [60].

4) Random error. Even though there may be no relation between a gene expression and prognosis, false positives may be detected by chance.
Thus, one needs to regard the results from PrognoScan in the context of complex conditions. Currently, PrognoScan provides curated information such as cohort, therapy history, pathological parameters and array type to aid in the interpretation of the results. As a next step, developing an "interpreter" for complex meta-analysis result is tempting and we are now contemplating the challenge. In the meantime, we will continue collecting published datasets and will update PrognoScan every 6 months. Increased data content will help the judgment of the robustness of the prognostic value of a gene.

Further plans for PrognoScan also include development of the algorithm for finding multiple cutpoints. From the limited computational resources, cutpoint selection is currently done for two-way (high and low) expression grouping. For clinical practice, three-way (high, intermediate, and low) expression grouping can also be used. Thus, we are trying to develop a grid search algorithm, demonstrated as the "X-Tile" tool [61]. In summary, this new database provides a powerful platform for evaluating potential tumor markers and therapeutic targets, and as a result, will accelerate cancer research. 


\section{Availability and requirements}

PrognoScan requires nothing other than a web browser and is available from the server at Kyushu Institute of Technology (KIT): http://gibk21.bse.kyutech.ac.jp/Prog noScan/index.html.

\section{Competing interests}

The authors declare that they have no competing interests.

\section{Authors' contributions}

$\mathrm{HM}$ and AS designed the database. KK and $\mathrm{KN}$ aided in the conception and design of the database. HM and KK participated in writing the manuscript. All authors read and approved the final manuscript.

\section{Additional material}

\section{Additional file 1}

Full summary table for MKI67. A well known tumor proliferation marker MKI67 was assessed with PrognoScan and the summary table was indicated.

Click here for file

[http://www.biomedcentral.com/content/supplementary/17558794-2-18-S1.xls]

\section{Additional file 2}

Number of statistically significant tests for four proliferation markers among nine cancer types. Tumor proliferation markers, TOP2A, PCNA and Aurora A were assessed with PrognoScan. Together with the result for MKI67, associations with nine cancer types were indicated.

Click here for file

[http://www.biomedcentral.com/content/supplementary/17558794-2-18-S2.xls]

\section{Acknowledgements}

We thank K. Kitajima of KIT for his technical support for database development and D. Schmitt and F. Ford of Chugai Pharmaceuticals for their helpful discussions and checking of the manuscript.

\section{References}

I. Elfilali A, Lair S, Verbeke C, La Rosa P, Radvanyi F, Barillot E: ITTACA: a new database for integrated tumor transcriptome array and clinical data analysis. Nucleic Acids Res 2006, 34:D613-6.

2. Abel U, Berger J, Wiebelt H: CRITLEVEL: an exploratory procedure for the evaluation of quantitative prognostic factors. Methods Inf Med 1984, 23:154-6.

3. Kronqvist $\mathrm{P}$, Kuopio T, Collan $\mathrm{Y}$ : Quantitative thresholds for mitotic counts in histologic grading: confirmation in nonfrozen samples of invasive ductal breast cancer. Ann Diagn Pathol 2000, 4:65-70.

4. Jensen KC, Turbin DA, Leung S, Miller MA, Johnson K, Norris B, Hastie T, McKinney S, Nielsen TO, Huntsman DG, Gilks CB, West RB: New cutpoints to identify increased HER2 copy number: analysis of a large, population-based cohort with long-term follow-up. Breast Cancer Res Treat 2008, I I 2:453-9.

5. Jeganathan K, Malureanu L, Baker DJ, Abraham SC, van Deursen JM: Bub I mediates cell death in response to chromosome missegregation and acts to suppress spontaneous tumorigenesis. J Cell Biol 2007, I 79:255-67.
6. Will E, Speidel D, Wang Z, Ghiaur G, Rimek A, Schiedlmeier B, Williams DA, Baum C, Ostertag W, Klump H: HOXB4 inhibits cell growth in a dose-dependent manner and sensitizes cells towards extrinsic cues. Cell Cycle 2006, 5:|4-22.

7. Shachaf CM, Gentles AJ, Elchuri S, Sahoo D, Soen Y, Sharpe O, Perez OD, Chang M, Mitchel D, Robinson WH, Dill D, Nolan GP, Plevritis SK, Felsher DW: Genomic and proteomic analysis reveals a threshold level of MYC required for tumor maintenance. Cancer Res 2008, 68:5I32-42.

8. Barrett T, Troup DB, Wilhite SE, Ledoux P, Rudnev D, Evangelista C, Kim IF, Soboleva A, Tomashevsky M, Edgar R: NCBI GEO: mining tens of millions of expression profiles - database and tools update. Nucleic Acids Res 2007, 35:D760-5.

9. Parkinson H, Kapushesky M, Shojatalab M, Abeygunawardena $N$, Coulson R, Farne A, Holloway E, Kolesnykov N, Lilja P, Lukk M, Mani R, Rayner T, Sharma A, William E, Sarkans U, Brazma A: ArrayExpress - a public database of microarray experiments and gene expression profiles. Nucleic Acids Res 2007, 35:D747-50.

10. Als AB, Dyrskjøt L, Maase $H$ von der, Koed K, Mansilla F, Toldbod HE, Jensen JL, Ulhøi BP, Sengeløv L, Jensen KM, Orntoft TF: Emmprin and survivin predict response and survival following cisplatin-containing chemotherapy in patients with advanced bladder cancer. Clin Cancer Res 2007, 13:4407-14.

II. Metzeler KH, Hummel M, Bloomfield CD, Spiekermann K, Braess J, Sauerland MC, Heinecke A, Radmacher M, Marcucci G, Whitman SP, Maharry K, Paschka P, Larson RA, Berdel WE, Büchner T, Wörmann B, Mansmann U, Hiddemann W, Bohlander SK, Buske C, Cancer and Leukemia Group B; German AML Cooperative Group: An 86probe-set gene-expression signature predicts survival in cytogenetically normal acute myeloid leukemia. Blood 2008, I | 2:4|93-20|.

12. Raponi M, Lancet JE, Fan H, Dossey L, Lee G, Gojo I, Feldman EJ, Gotlib J, Morris LE, Greenberg PL, Wright JJ, Harousseau JL, Löwenberg B, Stone RM, De Porre P, Wang Y, Karp JE: A 2-gene classifier for predicting response to the farnesyltransferase inhibitor tipifarnib in acute myeloid leukemia. Blood 2008, I I I:2589-96.

13. Hummel M, Bentink S, Berger H, Klapper W, Wessendorf S, Barth TF Bernd HW, Cogliatti SB, Dierlamm J, Feller AC, Hansmann ML, Haralambieva E, Harder L, Hasenclever D, Kühn M, Lenze D, Lichter P, Martin-Subero JI, Möller P, Müller-Hermelink HK, Ott G, Parwaresch RM, Pott C, Rosenwald A, Rosolowski M, Schwaenen C, Stürzenhofecker B, Szczepanowski M, Trautmann H, Wacker HH, Spang R, Loeffler M, Trümper L, Stein H, Siebert R, Molecular Mechanisms in Malignant Lymphomas Network Project of the Deutsche Krebshilfe: A biologic definition of Burkitt's lymphoma from transcriptional and genomic profiling. N Engl J Med 2006, 354:24l9-30.

14. Jais JP, Haioun C, Molina TJ, Rickman DS, de Reynies A, Berger F, Gisselbrecht $C$, Brière J, Reyes F, Gaulard $P$, Feugier $P$, Labouyrie E, Tilly H, Bastard C, Coiffier B, Salles G, Leroy K, Groupe d'Etude des Lymphomes de l'Adulte: The expression of 16 genes related to the cell of origin and immune response predicts survival in elderly patients with diffuse large B-cell lymphoma treated with CHOP and rituximab. Leukemia 2008, 22:1917-24.

I5. Zhan F, Huang Y, Colla S, Stewart JP, Hanamura I, Gupta S, Epstein J, Yaccoby S, Sawyer J, Burington B, Anaissie E, Hollmig K, PinedaRoman M, Tricot G, van Rhee F, Walker R, Zangari M, Crowley J, Barlogie $B$, Shaughnessy JD Jr: The molecular classification of multiple myeloma. Blood 2006, I 08:2020-8.

16. Chin K, DeVries S, Fridlyand J, Spellman PT, Roydasgupta R, Kuo WL, Lapuk A, Neve RM, Qian Z, Ryder T, Chen F, Feiler H, Tokuyasu T, Kingsley C, Dairkee S, Meng Z, Chew K, Pinkel D, Jain A, Ljung BM, Esserman L, Albertson DG, Waldman FM, Gray JW: Genomic and transcriptional aberrations linked to breast cancer pathophysiologies. Cancer Cell 2006, I0:529-4I.

17. Schmidt M, Böhm D, von Törne C, Steiner E, Puhl A, Pilch H, Lehr HA, Hengstler JG, Kölbl H, Gehrmann M: The humoral immune system has a key prognostic impact in node-negative breast cancer. Cancer Res 2008, 68:5405-13.

18. Ma XJ, Wang Z, Ryan PD, Isakoff SJ, Barmettler A, Fuller A, Muir B, Mohapatra G, Salunga R, Tuggle JT, Tran Y, Tran D, Tassin A, Amon $P$, Wang W, Wang W, Enright E, Stecker K, Estepa-Sabal E, Smith B, Younger J, Balis U, Michaelson J, Bhan A, Habin K, Baer TM, Brugge J, Haber DA, Erlander MG, Sgroi DC: A two-gene expression ratio predicts clinical outcome in breast cancer patients treated with tamoxifen. Cancer Cell 2004, 5:607-16. 
19. Pawitan Y, Bjöhle J, Amler L, Borg AL, Egyhazi S, Hall P, Han X, Holmberg L, Huang F, Klaar S, Liu ET, Miller L, Nordgren H, Ploner A Sandelin K, Shaw PM, Smeds J, Skoog L, Wedrén S, Bergh J: Gene expression profiling spares early breast cancer patients from adjuvant therapy: derived and validated in two populationbased cohorts. Breast Cancer Res 2005, 7:R953-64.

20. Wang Y, Klijn JG, Zhang Y, Sieuwerts AM, Look MP, Yang F, Talantov D, Timmermans M, Meijer-van Gelder ME, Yu J, Jatkoe T, Berns EM, Atkins D, Foekens JA: Gene-expression profiles to predict distant metastasis of lymph-node-negative primary breast cancer. Lancet 2005, 365:67I-9.

21. Sotiriou C, Wirapati $P$, Loi S, Harris A, Fox S, Smeds J, Nordgren $H$, Farmer P, Praz V, Haibe-Kains B, Desmedt C, Larsimont D, Cardoso F, Peterse H, Nuyten D, Buyse M, Vijver MJ Van de, Bergh J, Piccart $M$, Delorenzi M: Gene expression profiling in breast cancer: understanding the molecular basis of histologic grade to improve prognosis. J Natl Cancer Inst 2006, 98:262-72.

22. Bild AH, Yao G, Chang JT, Wang Q, Potti A, Chasse D, Joshi MB, Harpole D, Lancaster JM, Berchuck A, Olson JA Jr, Marks JR, Dressman HK, West M, Nevins JR: Oncogenic pathway signatures in human cancers as a guide to targeted therapies. Nature 2006, 439:353-7.

23. Miller LD, Smeds J, George J, Vega VB, Vergara L, Ploner A, Pawitan Y, Hall P, Klaar S, Liu ET, Bergh J: An expression signature for p53 status in human breast cancer predicts mutation status, transcriptional effects, and patient survival. Proc Natl Acad Sci USA 2005, I 02:13550-5.

24. Ivshina AV, George J, Senko O, Mow B, Putti TC, Smeds J, Lindahl T, Pawitan Y, Hall P, Nordgren H, Wong JE, Liu ET, Bergh J, Kuznetsov VA, Miller LD: Genetic reclassification of histologic grade delineates new clinical subtypes of breast cancer. Cancer Res 2006, 66: |0292-30|.

25. Loi S, Haibe-Kains B, Desmedt C, Wirapati P, Lallemand F, Tutt AM, Gillet C, Ellis P, Ryder K, Reid JF, Daidone MG, Pierotti MA, Berns EM, Jansen MP, Foekens JA, Delorenzi M, Bontempi G, Piccart MJ, Sotiriou $C$ : Predicting prognosis using molecular profiling in estrogen receptor-positive breast cancer treated with tamoxifen. BMC Genomics 2008, 9:239.

26. Zhou Y, Yau C, Gray JW, Chew K, Dairkee SH, Moore DH, Eppenberger U, Eppenberger-Castori S, Benz CC: Enhanced NF kappa B and AP-I transcriptional activity associated with antiestrogen resistant breast cancer. BMC Cancer 2007, 7:59.

27. Desmedt C, Piette F, Loi S, Wang Y, Lallemand F, Haibe-Kains B, Viale G, Delorenzi M, Zhang Y, d'Assignies MS, Bergh J, Lidereau R, Ellis $P$ Harris AL, Klijn JG, Foekens JA, Cardoso F, Piccart MJ, Buyse M, Sotiriou C, TRANSBIG Consortium: Strong time dependence of the 76-gene prognostic signature for node-negative breast cancer patients in the TRANSBIG multicenter independent validation series. Clin Cancer Res 2007, I3:3207-14.

28. Anders CK, Acharya CR, Hsu DS, Broadwater G, Garman K, Foekens JA, Zhang Y, Wang Y, Marcom K, Marks JR, Mukherjee S, Nevins JR, Blackwell KL, Potti A: Age-specific differences in oncogenic pathway deregulation seen in human breast tumors. PLoS ONE 2008, 3:el 373

29. Chanrion M, Negre V, Fontaine H, Salvetat N, Bibeau F, Mac Grogan G, Mauriac L, Katsaros D, Molina F, Theillet C, Darbon JM: A gene expression signature that can predict the recurrence of tamoxifen-treated primary breast cancer. Clin Cancer Res 2008 , I 4: 1744-52.

30. Murat A, Migliavacca E, Gorlia T, Lambiv WL, Shay T, Hamou MF, de Tribolet N, Regli L, Wick W, Kouwenhoven MC, Hainfellner JA, Heppner FL, Dietrich PY, Zimmer Y, Cairncross JG, Janzer RC, Domany E, Delorenzi M, Stupp R, Hegi ME: Stem cell-related "selfrenewal" signature and high epidermal growth factor receptor expression associated with resistance to concomitant chemoradiotherapy in glioblastoma. J Clin Oncol 2008, 26:3015-24.

31. Phillips HS, Kharbanda S, Chen R, Forrest WF, Soriano RH, Wu TD, Misra A, Nigro JM, Colman H, Soroceanu L, Williams PM, Modrusan Z, Feuerstein BG, Aldape K: Molecular subclasses of high-grade glioma predict prognosis, delineate a pattern of disease progression, and resemble stages in neurogenesis. Cancer Cell 2006, 9:157-73.

32. Chung CH, Parker JS, Ely K, Carter J, Yi Y, Murphy BA, Ang KK, ElNaggar AK, Zanation AM, Cmelak AJ, Levy S, Slebos RJ, Yarbrough WG: Gene expression profiles identify epithelial-to-mesen- chymal transition and activation of nuclear factor-kappaB signaling as characteristics of a high-risk head and neck squamous cell carcinoma. Cancer Res 2006, 66:8210-8.

33. Beer DG, Kardia SL, Huang CC, Giordano TJ, Levin AM, Misek DE, Lin L, Chen G, Gharib TG, Thomas DG, Lizyness ML, Kuick R, Hayasaka S, Taylor JM, lannettoni MD, Orringer MB, Hanash S: Geneexpression profiles predict survival of patients with lung adenocarcinoma. Nat Med 2002, 8:816-24.

34. Tomida S, Koshikawa K, Yatabe Y, Harano T, Ogura N, Mitsudomi T, Some M, Yanagisawa K, Takahashi T, Osada H, Takahashi T: Gene expression-based, individualized outcome prediction for surgically treated lung cancer patients. Oncogene 2004, 23:5360-70.

35. Raponi M, Zhang Y, Yu J, Chen G, Lee G, Taylor JM, Macdonald J, Thomas D, Moskaluk C, Wang Y, Beer DG: Gene expression signatures for predicting prognosis of squamous cell and adenocarcinomas of the lung. Cancer Res 2006, 66:7466-72.

36. Altman DG, Lausen B, Sauerbrei W, Schumacher M: Dangers of using "optimal" cutpoints in the evaluation of prognostic factors. I Natl Cancer Inst 1994, 86:829-35.

37. Mazumdar M, Glassman JR: Categorizing a prognostic variable: review of methods, code for easy implementation and applications to decision-making about cancer treatments. Stat Med 2000, 19: I13-32

38. Holländer N, Schumacher M: On the problem of using 'optimal' cutpoints in the assessment of quantitative prognostic factors. Onkologie 2001, 24:194-9.

39. Miller R, Siegmund D: Maximally selected chi square statistics. Biometrics 1982, 38:1011-16.

40. Brown DC, Gatter KC: Ki67 protein: the immaculate deception? Histopathology 2002, 40:2-II.

4I. Coletta RD, Christensen K, Reichenberger KJ, Lamb J, Micomonaco D, Huang L, Wolf DM, Muller-Tidow C, Golub TR, Kawakami K, Ford HL: The Sixl homeoprotein stimulates tumorigenesis by reactivation of cyclin AI. Proc Natl Acad Sci USA 2004, I 0 I:6478-83

42. Coletta RD, Christensen KL, Micalizzi DS, Jedlicka P, Varella-Garcia $M$, Ford HL: Sixl overexpression in mammary cells induces genomic instability and is sufficient for malignant transformation. Cancer Res 2008, 68:2204-I3.

43. Behbakht K, Qamar L, Aldridge CS, Coletta RD, Davidson SA, Thorburn A, Ford HL: Sixl overexpression in ovarian carcinoma causes resistance to TRAIL-mediated apoptosis and is associated with poor survival. Cancer Res 2007, 67:3036-42.

44. Ng KT, Man K, Sun CK, Lee TK, Poon RT, Lo CM, Fan ST: Clinicopathological significance of homeoprotein Six I in hepatocellular carcinoma. Br J Cancer 2006, 95:1050-5.

45. Ford HL, Kabingu EN, Bump EA, Mutter GL, Pardee AB: Abrogation of the $\mathbf{G} 2$ cell cycle checkpoint associated with overexpression of HSIXI: a possible mechanism of breast carcinogenesis. Proc Natl Acad Sci USA 1998, 95: 12608-13.

46. Reichenberger KJ, Coletta RD, Schulte AP, Varella-Garcia M, Ford $\mathrm{HL}$ : Gene amplification is a mechanism of Six I overexpression in breast cancer. Cancer Res 2005, 65:2668-75.

47. Prosniak M, Dierov J, Okami K, Tilton B, Jameson B, Sawaya BE, Gartenhaus RB: A novel candidate oncogene, MCT-I, is involved in cell cycle progression. Cancer Res 1998, 58:4233-7.

48. Levenson AS, Thurn KE, Simons LA, Veliceasa D, Jarrett J, Osipo C Jordan VC, Volpert OV, Satcher RL Jr, Gartenhaus RB: MCT-I oncogene contributes to increased in vivo tumorigenicity of MCF7 cells by promotion of angiogenesis and inhibition of apoptosis. Cancer Res 2005, 65:1065I-6.

49. van't Veer LJ, Dai H, Vijver MJ van de, He YD, Hart AA, Mao M, Peterse HL, Kooy K van der, Marton MJ, Witteveen AT, Schreiber G], Kerkhoven RM, Roberts C, Linsley PS, Bernards R, Friend SH: Gene expression profiling predicts clinical outcome of breast cancer. Nature 2002, 4I5:530-6.

50. Mehra R, Varambally S, Ding L, Shen R, Sabel MS, Ghosh D, Chinnaiyan AM, Kleer CG: Identification of GATA3 as a breast cancer prognostic marker by global gene expression meta-analysis. Cancer Res 2005, 65: I 1259-64.

5I. Paulson KE, Rieger-Christ K, McDevitt MA, Kuperwasser C, Kim J, Unanue VE, Zhang X, Hu M, Ruthazer R, Berasi SP, Huang CY, Giri D, Kaufman S, Dugan JM, Blum J, Netto G, Wazer DE, Summerhayes IC, Yee AS: Alterations of the HBP I transcriptional repressor are 
associated with invasive breast cancer. Cancer Res 2007, 67:6136-45

52. Kim SS, Shago M, Kaustov L, Boutros PC, Clendening JW, Sheng $Y$, Trentin GA, Barsyte-Lovejoy D, Mao DY, Kay R, Jurisica I, Arrowsmith CH, Penn LZ: CUL7 is a novel antiapoptotic oncogene. Cancer Res 2007, 67:9616-22.

53. Dai H, van't Veer L, Lamb J, He YD, Mao M, Fine BM, Bernards R, Vijver M van de, Deutsch P, Sachs A, Stoughton R, Friend S: A cell proliferation signature is a marker of extremely poor outcome in a subpopulation of breast cancer patients. Cancer Res 2005, 65:4059-66.

54. Schrag D, Cramer LD, Bach PB, Cohen AM, Warren JL, Begg CB: Influence of hospital procedure volume on outcomes following surgery for colon cancer. JAMA 2000, 284:3028-35.

55. Bilimoria KY, Bentrem DJ, Ko CY, Tomlinson JS, Stewart AK, Winchester DP, Talamonti MS: Multimodality therapy for pancreatic cancer in the U.S. Cancer 2007, I I 0:1227-34.

56. Vernooij F, Heintz AP, Witteveen PO, Heiden-van der Loo M van der, Coebergh JW, Graaf $Y$ van der: Specialized care and survival of ovarian cancer patients in The Netherlands: nationwide cohort study. J Natl Cancer Inst 2008, 100:399-406.

57. Mizuarai S, Takahashi K, Kobayashi T, Kotani H: Advances in isolation and characterization of homogeneous cell populations using laser microdissection. Histol Histopathol 2005, 20:139-46.

58. Mazumder A, Wang Y: Gene-expression signatures in oncology diagnostics. Pharmacogenomics 2006, 7:1 167-73.

59. Irizarry RA, Bolstad BM, Collin F, Cope LM, Hobbs B, Speed TP: Summaries of Affymetrix GeneChip probe level data. Nucleic Acids Res 2003, 3 I:el 5.

60. Draghici S, Khatri P, Eklund AC, Szallasi Z: Reliability and reproducibility issues in DNA microarray measurements. Trends Genet 2006, 22:101-9.

61. Camp RL, Dolled-Filhart M, Rimm DL: X-tile: a new bio-informatics tool for biomarker assessment and outcome-based cutpoint optimization. Clin Cancer Res 2004, 10:7252-9.

\section{Pre-publication history}

The pre-publication history for this paper can be accessed here:

http://www.biomedcentral.com/1755-8794/2/18/prepub

Publish with Bio Med Central and every scientist can read your work free of charge

"BioMed Central will be the most significant development for disseminating the results of biomedical research in our lifetime. "

Sir Paul Nurse, Cancer Research UK

Your research papers will be:

- available free of charge to the entire biomedical community

- peer reviewed and published immediately upon acceptance

- cited in PubMed and archived on PubMed Central

- yours - you keep the copyright 